\title{
Gambaran Perubahan Psikososial dan Sistem Pendukung pada Orang dengan HIV/AIDS (ODHA) di Rumah Cemara Gegerkalong Bandung
}

\author{
Rizka Amalia $^{1}$, Sri Sumartini ${ }^{2 *}$, Afianti Sulastri ${ }^{3}$ \\ ${ }^{1}$ Mahasiswa Prodi D3 Keperawatan FPOK Universitas Pendidikan Indonesia, Bandung, Indonesia \\ ${ }^{2,3}$ Dosen Prodi D3 Keperawatan FPOK Universitas Pendidikan Indonesia, Bandung, Indonesia \\ *Email korespondensi: srisumartini@upi.edu
}

\section{ARTICLE INFO}

HOW TO CITED:

Amalia, R., Sumartini, S., \& Sulastri, A. (2018). Gambaran Perubahan Psikososial dan Sistem Pendukung pada Orang dengan HIV/AIDS (ODHA) di Rumah Cemara Gegerkalong Bandung. Jurnal Pendidikan Keperawatan Indonesia 4(1), 77-85

DOI:

10.17509/jpki.v4i1.12346

ARTICLE HISTORY:

Accepted

March 15, 2018

Revised

May11, 2018

Published

June 30, 2018

\section{A B S T R A K}

Penelitian ini dilatarbelakangi penderita setelah terinfeksi HIV/AIDS mengalami perubahan fisik dan psikis karena harus menyesuaikan diri dengan kondisi yang baru dalam hidupnya. AIDS adalah menurunnya daya tahan tubuh yang diakibatkan oleh virus HIV. Stigma yang negatif dan diskriminasi oleh masyarakat membuat ODHA (Orang Dengan HIV/AIDS) mempunyai kondisi yang semakin melemah, bahkan depresi. Motivasi hidup adalah suatu keyakinan dan dorongan bagi diri sendiri yang akan mempengaruhi individu bersikap dalam menghadapi situasi yang beragam. Penelitian menggunakan metode kualitatif dengan desain fenomologi deskriptif dan menggunakan sampel teknik purposive sampling. Tujuan penelitian ini adalah mengidentifikasi gambaran motivasi pada orang dengan HIV/AIDS di Rumah Cemara Geger Kalong Bandung. Teknik pengumpulan data menggunakan teknik wawancara, keabsahan data diuji dengan triangulasi. Sejumlah 10 informan (4 ODHA dan 4 anggota keluarga dan 2 pengurus ODHA) berpartisipasi dalam penelitian. Hasil penelitian ini menunjukan adanya beberapa perubahan terutama pada aspek fisik, psikologis, sosial dan sistem pendukung. Penderita ODHA mempunyai semangat untuk bekerja, semangat untuk bersosialisasi, semangat untuk berkarya dan pikiran yang positif. ODHA membutuhkan dukungan dari keluarga dan dukungan dari teman sebaya (peer support), dengan adanya stigma dan diskriminasi dari masyarakat seringkali ODHA tidak mau membuka status mereka karena takut dan khawatir. Faktor utama yang mempengaruhi Perubahan psikologi ODHA adalah optimisme hidup yang kuat dalam diri penderita. Dengan Keyakinan positif dalam kehidupan dan sistem pendukung yang dapat baik mampu membawa ODHA untuk memiliki tujuan hidup yang bermakna setelah terinfeksi HIV/AIDS.

Kata kunci: Perubahan Psikososial, Sistem Pendukung, ODHA

\section{A B S T R A C T}

Background of the present study is the physical and psychological changes of the individual after infected by HIV/AIDS that s/he has to adjust to the different condition in his/her life. AIDS is the decrease of body immune caused by HIV virus. Negative stigma and society discrimination weaken the condition of PLWHA (People Living with HIV/AIDS), even depression. Life motivation is a self-belief and self-push, which will influence an individual in facing varied situation.The study employs qualitative method with descriptive phenomenological research design and utilizes purposive sampling technique. The aim of the present study is to identify a motivation description of PLWHA 
at Rumah Cemara, Geger Kalong, Bandung. Data collection is derived from interview technique, while the data validity is tested by triangulation. There are ten respondents (4 PLWHA, 4 family members and 2 PLWHA nurses/social workers) taking part in the study. The result of this research indicated some changes especially in physical aspects, psychological, social and support system.The spirit odha have to work, vigor to socialize, vigor to work and mind positive. PLWHA needs support from family and support from their peers (peer support), with the stigma and discrimination of people often PLWHA do not want to open their status for worry. The main factors that effecting amendment psychology odha is strong optimism living in patients. With confidence positive in life and the support system that can both be able to take odha to have meaningful goal after infected with HIVI AIDS.

Keywords: Psychosocial Change, Support System, PLWHA

\section{PENDAHULUAN}

Acquired Immunodefiency Syndrome (AIDS) adalah kumpulan gejala yang timbul akibat menurunnya sistem kekebalan tubuh yang didapat, disebabkan oleh infeksi Human Immunodeficiency Virus (HIV). Virus ini menyerang dan merusak sel-sel limfosit T CD4+ sehingga kekebalan penderita rusak dan rentan terhadap berbagai infeksi. AIDS ini bukan suatu penyakit saja, tetapi merupakan gejala-gejala penyakit yang disebabkan oleh infeksi berbagai jenis mikroorganisme seperti infeksi bakteri, virus, jamur, bahkan timbulnya keganasan akibat menurunnya daya tahan tubuh penderita (Muartustik, 2008).

Berdasarkan data tahun 2012 dari Dinas Kesehatan Jawa Barat diketahui sampai tahun 2012 sebanyak 4.865 kasus. Dengan rata-rata pertahunnya di Jawa Barat ditemukan kasus AIDS sebanyak 540 kasus. Penemuan kasus AIDS tertinggi tahun 2012 untuk wilayah adalah Kabupaten Subang dengan penemuan 175 kasus. Kasus di jawa barat merupakan urutan ke empat terbesar di indonesia.

Menurut Kementrian Kesehatan Republik Indonesia (2015) Secara kumulatif sampai bulan desember 2015 jumlah kasus HIV di Indonesia yang dilaporkan adalah 30.935 orang kasus. Sedangkan kumulatif kasus AIDS di indonesia yang dilaporkan sebanyak 6.081 orang. Secara kumulatif 2015 jumlah kasus HIV positif terbanyak dilaporkan dari provinsi DKI Jakarta (4.695) adanya penurunan dibandingkan ditahun 2014 (5.851), Jawa Timur (4.155) adanya penurunan dibandingkan ditahun 2014 (4.508), Papua (3.494) adanya peningkatan 2014 (3.278), Jawa Barat (3.741), dan Jawa Tengah (3.005) terjadi peningkatan dibandingkan tahun 2014 (2.867). Rasio kasus AIDS antara laki-laki dan perempuan adalah $2: 1$. Cara penularan kasus HIV kumulatif yang dilaporkan lalui heteroseksual $(47,7 \%)$, lelaki seks lelaki (22\%), lain-lain (28\%) dan penggunaan jarum suntik tidak steril pada penasun (penggunaan narkoba suntik) (3\%). Sedangkan Cara penularan kasus AIDS kumulatif yang dilaporkan melalui heteroseksual (80,3\%), LSL (Lelaki Seks Lelaki) (8\%), dari ibu positif HIV ke anak $(4,1 \%)$, dan penggunaan jarum suntik tidak steril pada penasun $(2,6 \%)$. Proporsi kumulatif kasus HIV tertinggi dilaporkan pada kelompok umur 20- 24 tahun (17\%), disusul kelompok umur 25-49 tahun (69\%) dan kelompok umur $\geq 50$ tahun $(7 \%)$. Sedangkan Proporsi kumulatif kasus AIDS tertinggi dilaporkan pada kelompok umur 20-29 tahun $(27,9 \%)$, kemudian kelompok umur 30- 39 tahun $(37,3 \%)$ dan kelompok umur 40-49 tahun (18,8\%). Proporsi kasus AIDS menurut tahun 2000 sampai dengan Desember 2015 dilaporkan telah meninggal 0,95\%. Infeksi Oportunistik yang terbanyak adalah TBC (187), Kandidiasis (191), Diare (187), Dermatitis (79) dan Herpes Simplex (38) (Kemenkes, 2015). Orang Dengan HIV/AIDS (ODHA) yang telah menjadi anggota Rumah Cemara adalah 1.276 orang.

Menurut Muma penelitian sebelum nya menunjukan bahwa bagi individu yang positif terinfeksi HIV, menjalani kehidupannya akan 
terasa sulit sekalipun itu dialami oleh orangorang dewasa yang sejatinya telah memiliki kematangan hidup, karena dari segi fisik individu tersebut akan mengalami perubahan yang berkaitan dengan perkembangan penyakitnya, tekanan emosional dan stres psikologis yang dialami karena dikucilkan oleh keluarga dan teman karena takut tertular, serta adanya stigma sosial dan diskriminasi di masyarakat. Hal ini berdampak pada respons sosial (emosional) pasien, sebagai contoh adanya stigma sosial yang dapat menyebabkan gangguan perilaku pada orang lain, termasuk menghindari kontak fisik dan sosial (Nihayati, 2012).

\section{METODE}

Metoda yang digunakan adalah deskriptif kualitatif, lokasi Penelitian ini dilakukan di Rumah Cemara Jl. Geger kalong Girang No. 52 Bandung Jawa Barat. Rumah Cemara merupakan kelompok terbesar HIV/AIDS dan orang yang menggunakan narkoba di Jawa Barat, Indonesia. Rumah Cemara telah merawat 4.317 orang dengan HIV / AIDS dengan pengguna narkoba, 1.276 orang yang terkena HIV / AIDS dalam 61 kelompok dukungan sebaya, yang berada di 3 lokasi Bandung, Sukabumi, dan Cianjur.

Hal yang menjadi bahan pertimbangan utama dalam pengumpulan data adalah pemilihan informan. Dalam penelitian kualitatif tidak digunakan istilah populasi. Teknik sampling yang digunakan oleh peneliti adalah purposive sample. Pada penelitian ini pemilihan partisipan menggunakan teknik purposive yaitu pengambilan partisipan sebagai sumber data dengan pertimbangan tertentu dan berdasarkan kriteria yang telah ditentukan Polit \& Beck (2010, dalam Kurniawan, 2015).

Populasi sampel yang digunakan adalah ODHA yang telah menjadi anggota Rumah Cemara. Kriteria partisipan yang akan diambil pada penelitian ini berdasarkan pada: 1) Menjadi anggota Rumah Cemara; 2) Partisipan dapat berkomunikasi dengan baik; dan 3) Bersedia menjadi partisipan.

Penelitian ini menggunakan tekhnik wa- wancara mendalam (in-depth interview) dan triangulasi dimaksudkan untuk mendapatkan keterangan dari beberapa pihak secara terpisah namun dengan karakteristik yang sama kemudian hasilnya di cross check antara jawaban yang satu dengan yang lainnya. Pengertiannya triangulasi adalah teknik pemeriksaan keabsahan data yang memanfaatkan sesuatu yang lain dalam membandingkan hasil wawancara terhadap objek penelitian (Moloeng dalam Sugiyono, 2012).

\section{HASIL}

Karakteristik Partisipan (1), (2), (3) dan (4) merupakan pengguna narkoba dengan penggunaan alat injeksi secara bersamaan dengan pengguna narkoba lainnya, mendapatkan diskriminasi dari lingkungan, merasa menurunnya harapan hidup dan takut tidak adanya dukungan keluarga.

\section{Perubahan saat terinfeksi HIV/AIDS}

\section{a. Perubahan aspek fisik}

ODHA ketika mengalami HIV positif, menimbulkan dampak kompleks yang dialami partisipan, terkait perubahan fisik.

Teridentifikasi tema berikut ini: Perubahan berat badan Perubahan yang terjadi misalnya, diare berkepanjangan. Hal ini sesuai dengan ungkapan partisipan: partisipan kedua dan ketiga mengatakan, “...saat itu saya mengalami tanda-tanda dari HIV, berat badan saya turun drastic..."(P2) (P3).

1) Diare berkepanjangan

Hal ini sesuai dengan ungkapan partisipan ke empat:"..hmm sebelum saya mengetahui saya HIV saya kaya diare terus menerus. saya pikir tuh biasa aja, tapi ini tiap pagi siang sore malem suka mules aja." (P4).

2) Herpes

Ketika terinfeksi HIV, partisipan keempat mengatakan mengalami herpes pada seluruh tubuhnya. Hal ini sesuai yang diungkapkan partisipan: “..saya waktu itu mba gatel-gatel melendung gitu sekujur tubuh, tapi ibu saya sangat merawat saya dan dikasih obat tradisional gitu biar kulit saya ga ada bekas herpesnya.." (P4) 
HIV ini disebabkan terutama karena proses imunosupresif yang berat dan keadaan ini menyebabkan tubuh pengidap HIV menjadi rentan terhadap infeksi oportunistik (Muartustik, 2008).

\section{b. Perubahan pada aspek psikologis}

Semua partisipan mengalami perubahan aspek psikologis melalui dua tahapan yaitu :

1) Tahap satu :

Respon ketika dinyatakan positif terinfeksi HIV/AIDS, berbagai respon muncul antara lain keinginan untuk bunuh diri, rasa sedih, penerimaan status dan pemakai narkoba bertambah.

a) Putus asa

Ketika terinfeksi HIV positif, ada empat partisipan yang menyatakan terkadang menurun semangatnya. Berdasarkan hasil: Partisipan pertama dan kedua mengatakan "kadang kuat menghadapi ini, kadang down.." "saya sempet down banget setelah saya mengetahui status dan bagaimana caranya mengetahui orangtua saya.. pikiran mau mati.. " $(\mathrm{P} 1)$ (P2).

b) Ingin bunuh diri

Keinginan untuk bunuh diri ketika terinfeksi HIV, sedih, takut akan status pada dirinya diungkapkan oleh dua orang partisipan yaitu partisipan pertama dan kedua, alasan yang diungkapkan karena takut mengungkapkan status nya pada orang tua dan ingin mengakhiri hidup, seperti ungkapan berikut : "Kaget, sempat menolak, takut menyodorkan hasil dari dokter dan ingin rasanya bunuh diri saja”.. (P1) " Pada saat ditinggal oleh istri rasanya saya ingin mati, tidak ada gunanya lagi untuk hidup..."(P2) penelitian Safarina, 2012 menyatakan yang berada pada fase depresi sering menunjukan sikap menarik diri, tidak mau bicara, kurang minat dan motivasi, putus asa dan menangis. Kadang-kadang c) Rasa Sedih

Rasa sedih diungkapkan oleh partisipan ketiga yang dinyatakan positif HIV, hal ini sesuai dengan ungkapan partisipan : “ Sedih nggak abis-abis.. bayangin anak masih kecil dan saya bingung memberitahukan kepada orang tua saya.. ancur perasaan saya.. sedih.." (P3)

Penelitian ini didukung oleh Safarina, 2012 semua klien yang menjadi partisipannya menunjukan kesedihan yang mendalam dengan menangis hampir setiap waktu dan malu untuk bertemu dengan orang-orang sekitarnya

d) Pemakaian narkoba bertambah

“..hmm saya kaget, setelah saya tahu HIV saya ingin bunuh diri dan dari situ saya bingung harus gimana, dan yaitu narkoba saya semakin parah..” (P1) "..Ketika saya melihat hasil dokter dan dokter mengatakan saya HIV saya bingung dan saya memberitahu istri saya dan setelah itu istri saya tinggalin saya ya saya pake narkoba nya nambah.." (P2)

"..wah mba pas saya tau saya HIV saya bingung harus gimana, ya jadi pelarian saya ke narkoba lagi.." (P4)

Hal ini diperkuat dengan adanya peneitian bahwa keputusasaan dapat terjadi ketika menghadapi perubahan siklus kehidupan, kondisi sosial dan historis, serta kefanaan hidup di hadapan kekekalan hidup (kematian). Akibatnya, seseorang kadang mengalami perasaan tentang hidup mereka tidak berarti lagi. Akibat sakit mengakibatkan adanya gangguan emosi terkait dengan neurosis, yaitu adanya kesalahan penyesuaian diri secara emosional karena konflik tidak sadar yang tidak dapat diselesaikan dengan baik (Sunaryo, 2013).

2) Tahap kedua : respon setelah lama terinfeksi HIV/AIDS

a) Mampu menerima 
Partisipan pertama, kedua, ketiga dan keempat ingin bunuh diri pada akhirnya menerima statusnya. Menurut partisipan pertama, keempat pada awalnya tidak menerima akan tetapi setelah mendapat dukungan keluarga dapat menerimanya. Partisipan kedua dan ketiga pada awalnya menolak, akan tetapi karena ingin menunjukan kepada orang yang telah mencemoohkannya dia mampu menerima. Hal ini sesuai dengan pernyataan partisipan :

"Ya karena kesalahan saya pada awalnya jadi saya menerima konsekwensinya " (P2)

“.. ya karena udah terjadi dan saya punya anak yang masih kecil mau ga mau saya harus tetep sehat dan nerima status saya.. " (P3)

" ..awalnya saya sempat bingung karena memberi-tahukan keluarga saya, tapi setelah mereka tau dan bahkan respon mereka memberi saya semangat saya bisa menerima dengan status saya..” (P1) “..karena support keluarga dan pihak Cemara ke rumah sakit memotivasi saya disitusaya jadi berpikir, masa dia juga bisa masa gue engga.. dan akhirnya saya menerima status saya"

Hal ini diperkuat oleh Nursalam, 2007 seseorang mulai dapat beradaptasi dengan keadaan serta berkurangnya kepedihan yang menyakitkan.

Adapun tahapan spesifik motivasi penderita ODHA adalah sebagai berikut:

1) Tahap satu : penurunan motivasi

Dialami seluruh partisipan setelah mengetahui terinfeksi HIV adanya rasa takut mengakibatkan penurunan motivasi karena stigma masyarakat dan motivasi diri.

Partisipan satu, kedua dan ketiga mengatakan setelah dokter mendiagnosa saya HIV, saya takut saya ingin bunuh diri dan saya menarik diri karena stigma orangorang sekitar (P1) (P2) (P4)

" mengetahui HIV dan adanya stigma saya ingin pindah rumah biar ga di omongin lagi..” (P3)
2) Tahap dua : Peningkatan Motivasi

Dialami seluruh partisipan setelah mengetahui terinfeksi HIV yang awalnya penurunan motivasi karena stigma dan dukungan serta motivasi dari pengurus Rumah Cemara dan paling utama saya ingin menunjukan kalau saya bisa berkarya.

Partisipan satu, kedua dan ketiga mengatakan karena adanya stigmadari masyarakat, dukungan keluarga dan motivasi dari Rumah Cemara saya jadi semangat untuk hidup dan meninggalkan barang haram itu, dan saya harus tunjukin yang udah ngehina gue kalau gue bisa berkarya melebihi mereka semua (P1) (P2) (P3) “..hmm yang awalnya gue mau bunuh diri tapi setelah kedatangan pengurus rumah cemara dan memberikan motivasi kepada gue, gue jadi semangat dan berpikir dia aja bisa kenapa gue engga dan gue beruntung punya orang tua kaya mereka yang selalu ada buat gue, gue sakit gini mereka yang ngurusin gue dan gue juga mau lah ngerasain berkeluarga kaya yang lain..” (P4)

Semua respon keluarga partisipan pun mendukung motivasi partisipan untuk bangkit dari penyakitnya :"ya awalnya saya kaget tapi ya masa saya gak kasih semangat ke anak saya. ya saya sih pengen anak saya sehat dan bisa bermanfaat walau kondisi nya kaya gitu.." (K1) “... hmm saya mah kesel teh, soalnya anak saya itu dulu nakal ya jadi saya kesel tapi ya namanya juga orang tua ga tega liat kondisi anak kaya gitu, ya saya kasih dukungan terus buat anak saya..” (K2) "..awal saya sempet kesel cuma yaudah mau gimana lagi, saya pasrah dan saya kasih motivasi ke anak saya dan saya pun mengantar anak saya kalau ke rumah sakit gitu mba.." (K3).

Siboro (2014) menggambarkan dalam penelitiaanya bahwa optimisme dapat mempengaruhi kesehatan, sehingga ODHA yang memiliki penghayatan hidup yang berfungsi akan memiliki optimisme, motivasi dan memiliki coping yang efektif dalam menghadapi tekanan-tekanan sehingga kondisi ini akan dapat membantu ODHA untuk tetap menjaga kesehatannya. 
c.Perubahan aspek sosial

1) Perubahan respon keluarga

a) Tahap I penolakan status meliputi :

(1) Marah

Ketika dinyatakan positif HIV/AIDS berbagai respon muncul antara lain marah, ketidakterimaan status adanya penerimaan status. Seperti ungkapan berikut : "..saya kaget, marah dan gak tau nak mau ngomong apa, campur aduk lah hati sama pikiran bapak, tapi bapak sadar mungkin ini kesalahan saya yang tak bisa membimbing anak.." (K1)

"..pengen rasanya ibu mati saja mendengar anak saya seperti itu, saya ingin sekali mencabik-cabik diri sendiri.." (K2)

"..Awalnya saya diem aja mba, marah iya tapi ya udahlah mau gimana lagi.." (K3)

(2)Ketidakterimaan Akan Status

Semua respon keluarga tidak menerima akan status nya, hasil yang didapatkan: " waah pas saya denger sendiri anak saya bilang HIV, nyess rasanya nak sakit banget, saya tidak nerima, tapi ya mungkin kesalahan saya..” (K1)

"..Saya tau anak saya HIV karena pada waktu itu menantu pertama saya sakit tertular HIV dan disitu saya beri tahu anak saya yang ada dipenjara dan anak saya baru jujur, hmm saya rasanya pengen mati aja mba. saya tidak terima.. " (K2)

"..saya tidak terima karena saya sudah menyekolahkan anak saya sampe perguruan tinggi dan saya tidak tau akan pergaulan nya di luar sana, ya mau gimana lagi..’(K3)

b) Tahap II penerimaan status meliputi :

Semua partisipan mengatakan dapat menerima akan status nya. setalah mengalami selama beberapa bulan. hasil yang didapatkan : “..mungkin karena ini saya kurang memperhatikan anak saya, saya nangis dan meluk anak saya nak.. " (K1)
“ ..awalnya saya diem aja mba sama anak saya, tapi ya udah lah mau gimana lagi udah terinfeksi dan saya harus menerimanya.." (K2)

"..saya rasanya mau mati mba, saya marahmarahin dia, tapi lama kelamaan ya udah lah, Cuma saya belum bisa ikhlas sama pekerjaannya sekarang.." (K3)

"ibu kaget mba, cuma ibu ga mau melihat anak ibu patah semangat dengan penyakitnya, jadi ibu terima dengan lapang dada.." (K4)

Keluarga memiliki peran penting dalam pendekatan masalah HIV/AIDS, arah dan strategi nasional penanggulangan $\mathrm{HIV} /$ AIDS (Keppres 36/94) pada hakekatnya ditujukan untuk meningkatkan ketahanan keluarga sejalan dengan UU pokok no 10 tahun 1992 tentang kependudukan dan keluarga sejahtera misalnya untuk perawatan penderita, peranan keluarga, baik keluarga batih maupun keluarga jaringan (nuclear and extended family) akan semakin dibutuhkan (Farlina, 2016).

2) Perubahan respon masyarakat

Semua partisipan mengatakan dapat menerima statusnya, dan cara pandang masyarakat pun dapat adanya stigma dari masyarakat dan penerimaan status dari partisipan. hasil yang didapatkan sebagai berikut :

a)Adanya Stigma Dari masyarakat

Partisipan satu, kedua dan ketiga mengatakan ada yang ngomongin saya di belakang, tapi yaudah sih ini hidup-hidup gu (P1) (P2) (P3)

Respon keluarga mengatakan adanya stig-

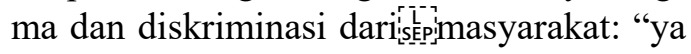
mereka pada jauhin saya nak, tapi saya coba buat baikdan menjelaskan ke mereka bahwa HIV itu tidak berbahaya, ya hari demi hari taun demi tahun akhirnya mereka bisa menerima keluarga saya dengan kondisi seperti ini.." (K1)

"..mungkin karena ini saya kurang memperhatikan anak saya, saya nangis dan meluk 
anak saya nak.. " (K1)

“. .awalnya saya diem aja mba sama anak saya, tapi ya udah lah mau gimana lagi udah terinfeksi dan saya harus menerimanya.." (K2)

“..saya rasanya mau mati mba, saya marahmarahin dia, tapi lama kelamaan ya udah lah, Cuma saya belum bisa ikhlas sama pekerjaannya sekarang.." (K3)

"ibu kaget mba, cuma ibu ga mau melihat anak ibu patah semangat dengan penyakitnya, jadi ibu terima dengan lapang dada.." (K4)

b) Menarik diri

Semua partisipan mengatakan menarik diri dikarenakan takut masyarakat sekitar.

Seperti ungkapan partisipan berikut : “..ya karena dapet cemoohan dari warga, ya sempet gamau keluar rumah, diajak arisan atau kumpul warga saya mending di rumah (P3) partisipan pertama dan kedua mengatakan hmm saya sempet gamau keluar rumah soalnya males dengerin omongan-omongan mereka yang engga-engga.. (P1) (P2) Respon keluarga pun adanya menarik diri dari masyarakat yaitu dengan hasil : “..ya mereka pada jauhin saya nak, saya sempat pindah rumah agar tetangga gak ngomongin keluarga saya lagi eh tau nya pas setaun kita kembali lagi tetep aja. Tapi saya coba buat baik dan menjelaskan ke mereka bahwa HIV itu tidak berbahaya, ya hari demi hari taun demi tahun akhirnya mereka bisa menerima keluarga saya dengan kondisi seperti ini.." (K3)

Self esteem adalah evaluasi tang dibuat oleh individu dan biasanya berhubungan dengan penghargaan terhadap dirinya sendiri, hal ini mengekpresikan suatu sikap setuju atau tidak setuju dan menunjukan tingkat dimana individu itu meyakini diri sendiri mampu, penting, berhasil dan berharga. Menurut Mechanic menarik diri adalah salah satu perasaan yang dapat muncul pada orang yang sakit kecemasan (ansietas), untuk mengatasi kecemasan salah satu caranya adalah menarik diri dari lingkungan (Sunaryo, 2013). Dalam penelitian Safarina, 2012 memberikan gambaran bahwa stigma merupakan suatu atribut atau lebel yang menyebabkan seseorang sangat tidak dihargai, dianggap mempunyai noda dan diabaikan.

\section{d. Sistem Pendukung Yang Ada}

Sistem pendukung yang ada digunakan dalam melakukan upaya mengatasi perubahan atau permasalahan yang timbul dengan motivasi hidupnya dan didiagnosis HIV merupakan faktor pendukung yang dapat memperkuat upaya yang dilakukan sistem pendukung meliputi sumber dukungan dan jenis dukungan yang di dapat. Sumber dukungan yang dapat berasal dari internal maupun eksternal keluarga, sedangkan jenis dukungan dapat berupa ekonomi, informasi atau semangat dan pendampingan.

1) Dukungan keluarga

Hasil identifikasi dari partisipan didapat hasil bahwa empat orang partisipan mendapat dukungan yang bersumber dari keluarga, seperti diungkapkan partisipan: "..keluarga ya mendukung.., dengan kondisi saya seperti ini..” (P2)

"..kedua orang tua saya yang selalu ada buat saya, disaat saya sedang sekarat di rumah sakit.." (P4)

"..pas saya kasih hasil dari dokter tentang penyakit saya, ya awalnya kaget. Tapi setelah itu bapak langsung meluk saya dan katanya saya harus berjuang.." (P1)

".. Melihat anak saya yang menjadi motivasi saya biar bangkit dan harus kerja keras biar sembuh.." (P3)

2) Dukungan dari petugas ODHA

Mendapatkan penjelasan dari petugas ODHA diungkapkan oleh semua partisipan, sesuai ungkapannya berikut: Semua partisipan mengungkapkan setelah saya lama di rawat rumah sakit ada petugas ODHA rumah cemara datang dan memberikan dukungan dan motivasi buat saya (P1) (P2) (P3) (P4)

Peer support atau dukungan sebaya adalah 
penyediaan dukungan emosional, informasi dan penilaian terhadap suatu jaringan sosial yang diciptakan anggota itu sendiri yang memiliki pengetahuan, keterampilan dan pengalaman dari perilaku tertentu dalam suatu populasi sejenis yang bertujuan untuk membantu mengatasi berbagai masalah yang muncul. Dukungan sebaya terbukti menjadi sumber penting dalam meningkatkan kualitas hidup pada ODHA Aktivitas yang dilakukan oleh dukungan sebaya antara lain memberikan konseling terhadap keluhan klien, memberikan pengetahuan tentang HIV/AIDS, mempermudah akses pelayanan kesehatan dan memberikan motivasi pada ODHA untuk patuh terhadap terapi (Surakarta, E. S. W. S. A, 2015).

\section{SIMPULAN}

Penelitian ini menemukan bahwa adanya beberapa perubahan pada saat terinfeksi HIV/ AIDS pada ODHA diantaranya adalah Perubahan aspek fisik ODHA, perubahan pada aspek psikologis, perubahan aspek sosial, dan sistem Pendukung yang ada. Didapat proses motivasi hidup ODHA (Orang Dengan HIV/AIDS) terjadi secara bertahap dan membutuhkan dukungan dari keluarga dan mendapat motivasi dari peer support atau dukungan sebaya. Adanya stigma dan diskriminasi dari masyarakat membuat ODHA seringkali tidak mau membuka status mereka ke orang lain karena mereka takut dan khawatir orang-orang akan menjauhi bahkan mengucilkan mereka dari lingkungan sekitarnya.

\section{DAFTAR PUSTAKA}

Dinkes Jabar. (2012). Profil Kesehatan Jawa Barat [Online]. Diakses dari http:// www.diskes.jabarprov.go.id/application/ modules/pages/files/ Cetak_Profil_Kesehatan_Revisi_11.pdf

Kemenkes RI. (2015). Laporan perkembangan HIV-AIDS triwulan IV Tahun 2015 [Online]. Diakses dari http://www.depkes. go.id/

Kurniawan, D. (2015). Pengalaman Hidup Pasien Mengalami Serangan Jantung Pertama Kali yang Dirawat Di Ruang CICU
RSUP DR. Hasan Sadikin Bandung. (Tesis). Fakultas Ilmu keperawatan. Departeman Keperawatan, Bandung

Muartustik, D. (2008). Infeksi Menular Seksual. Surabaya : Airlangga University Press.

Nihayati, A. (2012). Dukungan Sosial Pada Penyandang HIV/AIDS Dewasa (Doctoral dissertation, Universitas Muhammadiyah Surakarta)

Nursalam, M., Dian, N., \& Ns, S. K. (2011). Asuhan Keperawatan Pada Pasien Terinfeksi HIV/ AIDS. Jakarta : Salemba Medika.

Gusti, R. P., \& Farlina, M. (2016). Studi fenomologi pengalaman orang HIV/AIDS (ODHA) dalam mendekatkan dukungan keluarga di yayasan lantera minangkabau support padang. Jurnal Ners,11(1).

Polit, D. F. and Beck, T. C. 2006. Essential of Nursing Research. Method, Appraisal, and Utilization. Philadelphia: Lippincott Williams \& Wilkins

Safarina, L. (2012). Pengalaman Hidup Perempuan yang Terinfeksi HIV Dalam Menjalani Kehamilan (Tesis). Fakultas Ilmu keperawatan. Departeman Keperawatan, Bandung

Sugiyono. (2012). Metodologi Penelitian kuantitatif kualitatif dan $R \& D$. Bandung: Alfabeta

Sunaryo. (2013). Psikologi untuk keperawatan. Jakarta : EGC

Surakarta, E. S. W. S. A. (2015). Studi Fenomenologi: Makna ODHA Sebagai Tenaga Volunteer Peer Group Support ODHA Di Solo. IJMS-Indonesian Journal on Medical Science, 2(2). 
hlm.1-11.

Sirait, A. M., Sulistiowati, E., Sihombing, M., Kusuma, A., \& Idayani, S. (2015). Insiden dan Faktor Resiko Diabetes Melitus Pada Orang Dewasa Di Kota Bogor Studi Kohor Prospektif Faktor Resiko Penyakit Tidak Menular. Buletin Penelitian Sistem Kesehatan Vol. 18, hlm.151-160.

Solihah, S. N., Sari, C. W., \& Yamin, A. (2013). Faktor-faktor Yang Berhubungan Dengan Perilaku Perawatan Diri Pasien DM Tipe 2 Di Polikilinik Endokrin RSUP Hasan Sadikin Bandung. (Skripsi). Universitas Padjadjaran, Jatinangor.

Surjadi, C. (2013). Globalisasi dan Pola Makan Mahasiswa: Studi Kasus di Jakarta. CDK205 Vol 40 no 6, hlm.416-421.

Tafti, A. D., Mahmoodabad, S. S., Morowatisharifabad, M. A., Ardakani, M. A., Rezaeipandari, H., \& Lofti, M. H. (2015). Determinans od Self-Care in Diabetic Patients Based on Health Belief Model. Global Journal Health Science Vol. 7, hlm.33-42.
Vahidi, S., Shahmirzadi, S. E., Shojaeizadeh, D., Haghani, H., \& Nikpour, S. (2015). The effect of an Educational Program Based on the Health Belief Model on Self-Efficacy among Patients with Type 2 Diabetes Referred to the Iranian Diabetes Association in 2014. Journal of Diabetes Mellitus, hlm.181-189.

Vazini, H., \& Barati, M. (2015). The Health Belief Model and Self-Care Behaviors among Type 2 Diabetic Patients. Iranian Jornal Of Diabetes And Obesity Volume 6, hlm.107113.

WHO. (2015). 10 Facts About Diabetes. (Online). Diunduh dari http://www.who.int/ features/factsfile/diabetes/facts/en

WHO. (2015). 10 Facts on Obesity. (Online). Diunduh dari http://www.who.int/features/ factfiles/obesity/facts/en

WHO. (2015). Diabetes. (Online). Diunduh dari http://www.who.int/mediacentre/factsheets/ fs312/en/ 